\title{
Enkefalinazy jako nowy cel farmakologiczny w leczeniu chorób czynnościowych i zapalnych przewodu pokarmowego
}

\section{STRESZCZENIE}

$\mathbf{E}^{\mathrm{n}}$ nkefalinazy, należące do rodziny metaloproteaz zależnych od jonów cynku pełnią ważną rolę $w$ regulacji aktywności endogennego układu opioidowego (ang. endogenous opioid system, EOS). Inhibitory enkefalinaz pozwalają na zwiększenie stężenia wybranych endogennych peptydów opioidowych, co znalazło zastosowanie w lecznictwie. Pierwszym lekiem opartym na tym mechanizmie działania był racekadotryl, wykazujący działanie przeciwbiegunkowe. W przeciwieństwie do innych leków wpływających na aktywność EOS, stosowanie racekadotrylu wiąże się z niższym prawdopodobieństwem wystąpienia efektów ubocznych, co może być kluczowym kryterium przy doborze leczenia u pacjentów z przewlekłymi chorobami jelit, którym towarzyszy biegunka. Dominujący udział EOS w modulacji informacji nocyceptywnej stwarza również perspektywy do zastosowania inhibitorów enkefalinaz w leczeniu bólu. W pracy omówiono zastosowanie inhibitorów enkefalinaz $w$ chorobach układu pokarmowego, takich jak zespół jelita drażliwego oraz nieswoiste choroby zapalne jelit.

\section{WSTĘP}

Do ligandów receptorów opioidowych zaliczamy naturalne, półsyntetyczne oraz syntetyczne związki. Najlepiej poznanymi przedstawicielami tej grupy związków są morfina oraz kodeina, które szeroko wykorzystuje się w lecznictwie. Terapeutyczne właściwości morfiny znane były już w starożytności i pomimo upływu wieków nadal pozostaje ona jednym z najsilniej działających leków przeciwbólowych [1]. Rozwój medycyny umożliwił syntezę jej nowych pochodnych i rozszerzenie zastosowania terapeutycznego [2]. Poza leczeniem bólu, opioidy stosowane są m.in w terapii chorób układu pokarmowego. Niestety ich wykorzystanie jest mocno ograniczone z powodu występowania szeregu efektów ubocznych, z których najpoważniejszymi są lekozależność i zaparcia [3]. Wyzwaniem dla współczesnej medycyny i farmacji jest stworzenie leków o podobnym profilu i efektywności działania $\mathrm{z}$ ograniczeniem występowania działań niepożądanych. Alternatywą dla pacjentów zmagających się z przewlekłymi chorobami jelit mogą okazać się inhibitory enkefalinaz, które pośrednio aktywują receptory opioidowe [4]. Enkefalinazy są enzymami należącymi do rodziny metaloproteaz zależnych od jonów cynku, regulującymi aktywność układu opioidowego poprzez rozkład enkefalin, będących endogennymi ligandami receptorów opioidowych.

\section{TYPY RECEPTORÓW OPIOIDOWYCH}

Receptory opioidowe należą do grupy receptorów sprzężonych z białkiem $\mathrm{G}$ (ang. G protein-coupled receptor, GPCR), typu rodopsyny. Jest to najliczniejsza klasa, stanowiąca około $80 \%$ wszystkich GPCR w organizmie, obejmująca m.in. receptory adrenergiczne, kannabinoidowe, adenozynowe, dopaminowe i histaminowe. Receptory GPCR, nazywane inaczej receptorami 7-TM, zbudowane są z łańcucha polipeptydowego siedmiokrotnie przechodzącego przez dwuwarstwę lipidową; N-koniec znajduje się po zewnętrznej stronie błony komórkowej, natomiast C-koniec zlokalizowany jest wewnątrz komórki. Fragmenty zewnątrzkomórkowe odznaczają się dużym zróżnicowaniem pod względem sekwencji aminokwasów oraz konformacji przestrzenniej, co ma związek z wiązaniem specyficznych ligandów [5]. Aktywacja receptorów opioidowych prowadzi m.in. do otwarcia kanałów potasowych i hiperpolaryzacji błony komórkowej oraz zamknięcia kanałów wapniowych, a w konsekwencji hamowania wydzielania neuroprzekaźników do przestrzeni synaptycznej [6].

W wyniku badań nad fizjologią i strukturą receptorów opioidowych naukowcom udało się podzielić je na trzy typy: $\mu$ (ang. mu opioid receptor, MOR), $\delta$ (ang. delta opioid receptor, DOR) oraz $\mathrm{K}$ (ang. kappa opioid receptor, KOR). Wskazane typy receptorów opioidowych różnią się miedzy sobą sekwencją amino-

\section{Agata Twardowska,}

prof. dr hab. Jakub Fichna, mgr Agata Binienda ${ }^{\square}$

Zakład Biochemii, Katedra Chemii i Biochemii Medycznej, Uniwersytet Medyczny w Łodzi

https://doi.org/10.18388/pb.2020_344

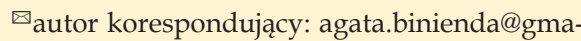
il.com

Słowa kluczowe: endogenny układ opioidowy, enkefalinazy, zespół jelita drażliwego, nieswoiste choroby zapalne jelit

Lista skrótów: ChLC - choroba Leśniowskiego-Crohna; DOR - receptor opioidowy $\delta$ (ang. delta opioid receptor, DOR); DSS - siarczan dekstranu sodu (ang. dextran sodium sulphate); EOS - endogenny układ opioidowy (ang. endogenous opioid system, EOS); GPCR - receptory sprzężone $\mathrm{z}$ białkiem $\mathrm{G}$ (ang. G protein-coupled receptor, GPCR); KOR - receptor opioidowy $\mathrm{k}$ (ang. kappa opioid receptor, KOR); NChZJ - nieswoiste choroby zapalne jelit; MOR - receptor opioidowy $\mu$ (ang. mu opioid receptor, MOR); TNBS - kwas 2,4,6-trinitrobenzenosulfonowy (ang. trinitrobenzenesulfonic acid, TNBS); WZJG - wrzodziejące zapalenie jelita grubego

Finansowanie: Praca finansowana ze środków na działalność statutową dla Zakładu Biochemii, Katedry Chemii i Biochemii Medycznej, Uniwersytet Medyczny w Łodzi (503/1-156-04/503-11-001-19-00 dla JF) oraz w ramach programu Diamentowy Grant finansowanego przez Ministerstwo Nauki i Szkolnictwa Wyższego (0229/DIA/2019/48 dla AB).

Wkład autorów: AT i AB przedstawiły ogólną koncepcję i ramy manuskryptu; AT opracowała bibliografię i napisała manuskrypt; AT stworzyła ryciny; AT, AB i JF poprawili manuskrypt. Wszyscy autorzy przeczytali i zatwierdzili ostateczną wersję manuskryptu. 
Tabela 1. Porównanie trzech typów receptorów opioidowych.

\begin{tabular}{llll} 
& Receptor $\mu$ & Receptor $\delta$ & Receptor k \\
\hline Inne nazwy & OP3, MOR, MOP & OP1, DOR, DOP & OP2, KOR, KOP \\
\hline Główni endogenni agoniści & Endomorfina A i Endomorfina B & Met-enkefalina i Leu-enkefalina & Dynorfina A i Dynorfina B \\
\hline Główni egzogenni agoniści & Morfina, Fentanyl, DAMGO & DPDPE & Cyklazocyna \\
\hline
\end{tabular}

kwasów, zwłaszcza w domenie zewnątrzkomórkowej, jak również rozmieszczeniem $\mathrm{w}$ organizmie, co przekłada się na różnice $\mathrm{w}$ działaniu biologicznym po związaniu ze swoistym ligandem [7]. Receptorem powiązanym z działaniem przeciwbólowym większości opioidów jest receptor MOR, który zawdzięcza swoją nazwę egzogennemu agoniście - morfinie. Ekspresja receptorów MOR zachodzi głównie w strukturach układu nerwowego powiązanych z percepcją bólu: I i II blaszce rdzenia kręgowego, jądrze rdzeniowym nerwu trójdzielnego, istocie szarej wokół wodociągu mózgu. Obecność tych receptorów stwierdzono także w strukturach mózgowia modulujących nastrój, takich jak hipokamp, jądro migdałowate oraz miejsce sinawe [8]. MOR odgrywa kluczową rolę w powstawaniu efektów ubocznych, towarzyszących terapii opioidami, włączając: depresje oddechową, zaparcia, nudności i wymioty [3]. Wszystkie trzy typy receptorów opioidowych ulegają ekspresji na powierzchni neuronów trzewnego układu nerwowego, gdzie biora udział w regulacji funkcjonowania układu pokarmowego. Poza układem nerwowym receptory opioidowe obecne są na powierzchni komórek mięśniowych jelit oraz żołądka, a także komórek układu immunologicznego [9]. Krótką charakterystykę typów receptorów opioidowych przedstawiono w Tabeli 1.

\section{ENDOGENNI AGONIŚCI RECEPTORÓW OPIOIDOWYCH}

W 1973 roku trzy niezależne grupy badawcze potwierdziły istnienie receptorów opioidowych w mózgu zwierząt (Per [10], Simon [11], Terenius [12]). Następnym krokiem w zrozumieniu fizjologii i znaczenia receptorów opioidowych była identyfikacja ich endogennych ligandów [13]. W 1975 roku Kosterlitz i wsp. wyizolowali z tkanki mózgowej świni, a następnie z płynu mózgowo-rdzeniowego człowieka związki wykazujące aktywność opioidową. Były to dwa pentapeptydy różniące się między sobą jedną resztą aminokwasową: Met- oraz Leu-enkefalina [14]. Do tej pory zidentyfikowano cztery grupy peptydów opioidowych: enkefaliny, $\beta$-endorfiny, dynorfiny, oraz endomorfiny. Różnice w sekwencji aminokwasów poszczególnych typów endogennych peptydów skutkują różnym powinowactwem tych związków względem receptorów opioidowych. Enkefaliny oraz endorfiny wykazują selektywność względem receptorów DOR i MOR, natomiast dynorfiny są głównymi agonistami receptora KOR, a ich powinowactwo do receptorów MOR i DOR jest niskie [15]. Każda rodzina endogennych opioidów powstaje z odrębnego białka prekursorowego, którego poziom ekspresji różni się w poszczególnych komórkach [14].
Prekursorem $\beta$-endorfiny jest białko proopiomelanokortyna, którego proteolityczne cięcie prowadzi do powstania m.in. hormonu adrenokortykotropowego oraz wspomnianej wcześniej $\beta$-endorfiny. Dynorfina A oraz dynorfina B powstają z pre-dynorfiny. Prekursorem enkefalin jest białko złożone z 267 aminokwasów - pro-enkefalina A. Jego proteolityczne cięcie prowadzi do powstanie czterech cząsteczek Met-enkefaliny, jednej cząsteczki Leu-enkefaliny, heptapeptydu zbudowanego z Met-enkefaliny i dwóch reszt aminokwasowych (argininy i fenyloalaniny) oraz oktapeptydu zbudowanego z Met-enkefaliny i trzech dodatkowych reszt aminokwasowych (argininy, glicyny i leucyny) [14].

\section{RECEPTORY OPIOIDOWE W PRZEWODZIE POKARMOWYM}

W przewodzie pokarmowym receptory opioidowe obecne są na powierzchni neuronów wchodzących w skład trzewnego układu nerwowego (neurony splotu mięśniówkowego i podśluzówkowego) oraz na komórkach mięśniowych jelit, gdzie biorą udział w regulacji funkcjonowania układu trawiennego. Aktywność receptorów opioidowych wpływa między innymi na perystaltykę jelit, wydzielanie soku żołądkowego, jelitowego oraz żółci, resorpcję wody i napięcie zwieraczy [3]. Efekty biologiczne wywołane aktywacją receptorów opioidowych obecnych w przewodzie pokarmowym przedstawiono w Tabeli 2.

U ludzi receptory MOR ulegają ekspresji w neuronach ruchowych splotu mięśniówkowego i podśluzówkowego zarówno jelita cienkiego, jak i grubego. Obecne są także na powierzchni komórek nerwowych kontrolujących wydzielanie soku żołądkowego i jelitowego [16] oraz w komórkach układu immunologicznego występujących $\mathrm{w}$ blaszce właściwej [17]. Wynikiem wiązania receptora MOR ze swoistym agonistą jest zwiększenie napięcia mięśni żołądka oraz opóźnienie jego opróżniania. Obserwuje się także zwiększenie napięcia zwieraczy: odbytu, przełyku oraz Oddiego. Ważnym efektem biologicznym warunkowanym pobudzeniem receptora MOR jest osłabienie perystaltyki jelit prowadzące do zwiększenia czasu pasażu treści pokarmowej [17].

Badania radiologiczne oraz immunohistochemiczne wykazały, że receptor DOR ulega ekspresji na powierzchni komórek immunologicznych blaszki właściwej oraz mięśni podłużnych [9]. W podśluzówkowym splocie nerwowym, receptory DOR obecne są na powierzchni neuronów przywspółczulnych (cholinergicznych i peptydergicznych) oraz neuronów układu współczulnego wydzielających tlenek 
Tabela 2. Efekty biologiczne aktywacji receptorów opioidowych w przewodzie pokarmowym.

\begin{tabular}{|c|c|}
\hline $\begin{array}{l}\text { Miejsce w przewodzie } \\
\text { pokarmowym }\end{array}$ & Efekt aktywacji receptorów opioidowych \\
\hline \multirow{3}{*}{ Żołądek } & Skurcz odźwiernika \\
\hline & $\begin{array}{l}\text { Hamowanie wydzielania } \\
\text { kwasu żołądkowego }\end{array}$ \\
\hline & Opóźnienie opróżniania \\
\hline \multirow{3}{*}{ Wątroba i drogi żółciowe } & $\begin{array}{l}\text { Skurcz pęcherzyka żółciowego } \\
\text { i dróg żółciowych }\end{array}$ \\
\hline & Skurcz zwieracza Oddiego \\
\hline & Hamowanie wydzielania żółci \\
\hline \multirow{2}{*}{ Jelito cienkie } & Hamowanie wydzielania soku jelitowego \\
\hline & Hamowanie skurczów perystaltycznych \\
\hline \multirow{4}{*}{ Jelito grube } & Wzmożona absorbcja wody \\
\hline & Wydłużenie czasu pasażu \\
\hline & Hamowanie ruchów perystaltycznych \\
\hline & Zwiększenie napięcia zwieracza odbytu \\
\hline
\end{tabular}

azotu (II) [18]. Aktywacja receptorów DOR występujących na powierzchni neuronów cholinergicznych prowadzi do zmniejszenia uwalniania acetylocholiny oraz wazoaktywnego peptydu jelitowego. Obniżone stężenie tego neuroprzekaźnika zmniejsza aktywność receptorów muskarynowych, stymulujących wydzielanie jonów chlorkowych, a w konsekwencji także wody do światła jelita. $W$ rezultacie związanie swoistego agonisty z receptorem DOR prowadzi do zagęszczenia kału, co wykorzystywane jest $\mathrm{w}$ terapii biegunek [4].

\section{ZASTOSOWANIE INHIBITORÓW ENKEFALINAZ W TERAPII BIEGUNEK}

Stosowanie agonistów receptorów opioidowych, takich jak loperamid czy difenoksylat, jest skuteczną strategią terapeutyczną wykorzystywaną w leczeniu biegunek. Leki te stosuje się $\mathrm{w}$ formie doustnych tabletek zawierających najczęściej $2 \mathrm{mg}$ loperamidu lub 2,5 mg difenoksylatu. Ponadto difenoksylat występuje $\mathrm{w}$ preparatach złożonych wraz z siarczanem atropiny. Struktury obu leków przedstawiono na Rycinie 1 [19]. Loperamid jest jednym z najczęściej stosowanych leków przeciwbiegunkowych w Polsce. Jako agonista MOR hamuje perystaltykę $\mathrm{w}$ jelicie grubym czego następstwem jest wydłużenie czasu pasażu treści pokarmowej oraz zmniejszenie wydzielania wody do świata jelita [20]. Ponadto zwiększenie napięcia spoczynkowego zwieracza odbytu znosi potrzebę natychmiastowego wypróżnienia. Pomimo wysokiej efektywności i szybkości działania, długotrwałe stosowanie agonistów receptora MOR może wiązać się z występowaniem efektów ubocznych, spośród których najczęściej obserwuje się zaparcia. Dodatkowo, wy- dłużenie czasu pasażu jelitowego może sprzyjać rozwojowi patogennych szczepów bakterii, zwłaszcza z rodzaju Salmonella, Shigella i Campylobacter, co uniemożliwia stosowanie loperamidu u chorych $\mathrm{z}$ niedoborami immunologicznymi (10). Z drugiej strony, terapeutyczne wykorzystanie endogennych agonistów receptorów opioidowych jest ograniczone ze względu na ich krótki okres półtrwania spowodowany obecnością w ustroju licznych enzymów degradujących. Jednym $z$ nich jest neprylizyna (enkefalinaza), należąca do rodziny metaloproteaz zależnych od jonów cynku. Substratami dla tego enzymu są zarówno peptydy i białka egzogenne, jak i endogenne włączając m.in. enkefaliny, substancję $\mathrm{P}$, neurotensynę, bradykininę oraz $\beta$-amyloid [21]. Inhibitory proteaz degradujących endogenne peptydy opioidowe umożliwiają przedłużenie okresu półtrwania m.in. enkefalin, co pozwala na osiągnięcie wysokiego stężenia tych związków w ustroju i wykorzystaniu ich naturalnego działania $w$ terapii. $W$ związku $\mathrm{z}$ tym jedna $\mathrm{z}$ najnowszych strategii terapeutycznych proponowana $w$ leczeniu biegunek opiera się na zwiększeniu stężenia endogennych peptydów opioidowych poprzez hamowanie ich rozkładu. Takie działanie charakteryzuje się zbliżoną efektywnością wobec stosowania egzogennych agonistów receptorów opioidowych, przy jednoczesnym ograniczeniu występowania efektów ubocznych [22]. Przykładem syntetycznego inhibitora enkefalinazy jest racekadotryl (acetorfan) wykazujący właściwości przeciwwydzielnicze w obrębie jelit [23]. Mechanizm jego działania został potwierdzony w modelach zwierzęcych z użyciem oleju rycynowego [24]. Racekadotryl charakteryzuje się słabym działaniem hamującym neprylizynę, natomiast $\mathrm{w}$ ustroju metabolizowany jest do 1000 razy silniejszego tiorfanu [23]. Struktury obu związków zostały przedstawione na rycinie 1 [23].

Zwiększenie stężenia Met-enkefaliny oraz Leu-enkefaliny w synapsach enkefalinergicznych, uzyskane poprzez hamowanie aktywności neprylizyny umożliwiło przedłużenie działania przeciwwydzielniczego peptydów, wywieranego za pośrednictwem receptorów DOR [23]. W 1999 roku Hamza i wsp. przeprowadzili podwójnie zaślepione badanie mające na celu porównanie skuteczności racekadotrylu $\mathrm{w}$ stosunku do placebo $\mathrm{w}$ terapii ostrej biegunki u dorosłych [22]. Kryterium kwalifikującym do leczenia było występowanie biegunki (definiowanej jako oddawanie minimum 3 wodnistych stolców dziennie) przez okres od jednej doby do pięciu dni. Z badania zostali wykluczeni pacjenci z prze-
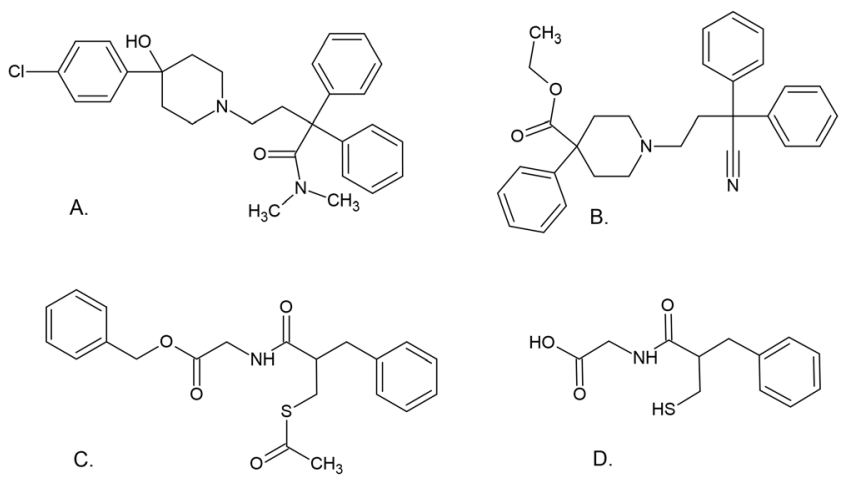

D.

Rycina 1. Struktury leków stosowanych w terapii biegunek: loperamidu (A), difenofksylatu (B), racekadotrylu (C) oraz tiorfanu (D). 
wlekłymi chorobami jelit oraz innymi schorzeniami współistniejącymi. Do analizy nie zostali także zakwalifikowani chorzy, u których w ciągu 7 dni przed rozpoczęciem terapii zastosowano inne leczenie farmakologiczne. Spośród 70 pacjentów biorących udział w badaniu, 32 zalecono przyjmowanie racekadotrylu w dawce 100 mg, 3 razy dziennie, pół godziny przed posiłkiem. Pozostałe 38 osób przyjmowało placebo z takim samym schematem dawkowania. Za koniec terapii uznano standardowe wypróżnienia w przeciągu 12 godzin. Miarą efektywności terapii była masa stolców oddanych podczas pierwszego dnia kuracji. Istotnymi parametrami były również: liczba wodnistych i standardowych wypróżnień w ciągu pierwszego dnia leczenia, a także obecność i natężenie dolegliwości towarzyszących biegunce, takich jak ból brzuszny, pieczenie odbytu, nudności oraz wymioty. Pod uwagę brano także inwazyjność terapii sprawdzaną za pomocą analizy krwi oraz moczu, a także występowanie efektów ubocznych mierzonych za pomocą kwestionariuszy. Średnia masa stolców oddanych w ciągu pierwszych 24 godzin terapii była o 28,9\% niższa w grupie leczonej racekadotrylem i wynosiła $335 \mathrm{~g} \mathrm{w}$ porównaniu z 499 g w grupie przyjmującej placebo. Po pierwszym dniu terapii liczba wodnistych wypróżnień u chorych leczonych racekadotrylem wynosiła średnio 4,3, podczas gdy w grupie placebo było to 5,4. Częstotliwość występowania efektów ubocznych (3,4\% pacjentów w grupie badanej i 5,3\% w grupie kontrolnej) oraz wpływ terapii na ogólny stan organizmu w obu przypadkach były na tym samym poziomie [22]. Podobne rezultaty otrzymano $\mathrm{w}$ badaniach przeprowadzonych przez Cezarda i wsp. [25] oraz Salazara-Lindo i wsp. [26], którzy analizowali skuteczność i bezpieczeństwo terapii racekadotrylem $\mathrm{u}$ dzieci.

W 1999 r. we Francji przeprowadzono badanie porównujące skuteczność loperamidu i racekadotrylu (31). Kryterium kwalifikującym do uczestnictwa w badaniu było występowanie ostrej biegunki przez okres od jednej doby do pięciu dni. Z analizy zostały wykluczone osoby, u których stwierdzono obecność krwi lub ropy w kale a także pacjenci z przewlekłymi schorzeniami jelit lub innymi chorobami współwystępującymi. Kwalifikacji do leczenia nie otrzymały również osoby, które w przeciągu 7 dni poprzedzających początek badania przyjmowały inne leki przeciwbiegunkowe oraz $\mathrm{u}$ których zastosowano antybiotykoterapię. Spośród 157 osób zaklasyfikowanych do badania, 82 osoby rozpoczęły terapię od przyjęcia racekadotrylu (100 mg) lub placebo, natomiast u pozostałych 75 osób zastosowano loperamid w dawce $2 \mathrm{mg}$ lub placebo. Ponadto zalecono pacjentom przyjmowanie racekadotrylu lub placebo przed każdym posiłkiem, podczas gdy grupa chorych leczona loperamidem przyjmowała standardową dawkę leku bądź placebo po każdym wodnistym stolcu. Za koniec terapii uznano dwa standardowe wypróżnienia w ciągu 12 godzin. Głównym kryterium skuteczności leczenia była liczba wodnistych stolców oddana do zakończenia kuracji. Istotnym parametrem był również czas mierzony od przyjęcia pierwszej dawki do ustąpienia objawów. Częstość występowania efektów ubocznych obserwowana była za pomocą personalnych kwestionariuszy oraz zgłaszana przez lekarzy na podstawie badania fizycznego. Średni czas trwania biegunki u pacjentów leczonych racekadotrylem wynosił 14,9 h w porównaniu do 13,7 h w grupie przyjmu- jącej loperamid. Liczba stolców oddanych do końca terapii była porównywalna w obu grupach i wynosiła średnio: 3,5 dla racekadotrylu oraz 2,9 dla loperamidu. Znaczące różnice pojawiły się jednak w częstości występowania efektów ubocznych po odstawieniu leczenia: 18,7\% pacjentów leczonych loperamidem doświadczyło zaparć, podczas gdy w grupie przyjmującej racekadotryl kłopoty z wypróżnianiem odnotowano tylko u 9,2\% osób (31).

Badanie porównujące skuteczność działania racekadotrylu i loperamidu zostało także przeprowadzone na grupie 945 osób pochodzących z 14 krajów rozwijających się. Kryteria kwalifikujące do leczenia nie różniły się znacząco od tych przyjętych w wyżej opisanej analizie. Spośród wszystkich pacjentów zaklasyfikowanych do badania, 473 rozpoczęło kurację od zażycia 100 mg racekadotrylu, który następnie przyjmowany był 3 razy dziennie aż do ustąpienia objawów. Podobny schemat zastosowany został w grupie chorych leczonych loperamidem, z tym, że dawka tego leku wynosiła $2 \mathrm{mg}$. Za koniec kuracji uznano brak wypróżnień lub 2 standardowe wypróżnienia w ciągu 12 godzin. Głównym parametrem określającym skuteczność terapii był czas trwania biegunki. Istotnymi czynnikami mierzonymi podczas leczenia były również: obecność i natężenie objawów współistniejących biegunce, takich jak ból brzuszny, wymioty czy nudności oraz występowanie efektów ubocznych. Średni czas trwania terapii był podobny w obu grupach i wynosił 48 h. 25\% pacjentów leczonych loperamidem doświadczyło zaparć (definiowanych jako brak wypróżnień w ciągu $36 \mathrm{~h}$ ), podczas gdy w grupie chorych przyjmujących racekadotryl było to tylko $16 \%$. Znaczace różnice pojawiły się także w czasie trwania wzdęć, które trwały 4,5 razy krócej u pacjentów leczonych racekadotrylem [32].

\section{POTENCJALNE ZASTOSOWANIE INHIBITORÓW ENKEFALINAZ W LECZENIU ZESPOŁU JELITA DRAŻLIWEGO}

Zespół jelita drażliwego (ZJD) to przewlekła choroba o charakterze czynnościowym i złożonej, niewyjaśnionej patogenezie. Przypuszcza się, że dotyka nawet do 15\% światowej populacji. Do charakterystycznych objawów ZJD należą: ból brzuszny, który jest głównym kryterium diagnostycznym, zmiana częstości oddawania stolca oraz jego konsystencji. W zależności od typu zaburzenia u zdiagnozowanych pacjentów może występować biegunka (nawet do 40\% przypadków) lub zaparcia. W niektórych przypadkach nieprawidłowości wypróżniania moga występować naprzemiennie lub nie pojawiać się w ogóle [27].

W związku z nieznaną patogenezą ZJD, u zdiagnozowanych pacjentów stosuje się leczenie objawowe. Pierwszym wskazaniem dla chorych jest zmiana stylu życia obejmująca głównie modyfikację diety. W przypadku braku poprawy stanu zdrowia wskazane jest zastosowanie środków farmakologicznych. W celu złagodzenia zaparć stosowane są lubiproston, linaklotyd, plekanatyd, natomiast loperamid, ryfaksymina a czy eluksadolina to preparaty wykorzystywane w przypadku biegunek [28]. Potencjalną alternatywą dla pacjentów cierpiących na ZJD z towarzyszącymi biegunkami może być racekadotryl wykazujący 
zbliżoną efektywność przeciwbiegunkową do loperamidu przy jednoczesnym ograniczeniu występowania efektów ubocznych [29].

W celu łagodzenia bólu, będącego głównym objawem ZJD, stosuje się leki rozkurczowe, antydepresanty oraz związki będące antagonistami receptora 5- $\mathrm{HT}_{3}$ [30]. Właściwości przeciwbólowe w obrębie przewodu pokarmowego wykazują również agoniści receptorów opioidowych [31]. Danzebrnik i wsp. udowodnili, że dordzeniowe podanie DAMGO, będącego selektywnym agonistą receptora MOR oraz DPDPE, selektywnego agonisty receptora DOR znacząco zmniejsza siłę skurczu mięśni brzusznych w mysim modelu bólu trzewnego spowodowanym rozciągnięciem ścian okrężnicy [32]. Ten sam efekt wywołało podanie selektywnych agonistów receptora KOR - U-69593 oraz asimadoliny, w badaniach przeprowadzonych przez Larssona i wsp. [33].

Oprócz działania przeciwbiegunkowego, inhibitory proteaz degradujących endogenne opioidy wykazują również właściwości modulujące przekazywanie informacji bólowej zarówno w ośrodkowym, jak i obwodowym układzie nerwowym. Mechanizm działania przeciwbólowego opiera się na zwiększeniu stężenia enkefalin, głównie Met-enkefaliny oraz Leu-enkefaliny w synapsach enkefalinergicznych, skutkując tym samym zmniejszeniem pobudliwości komórek nerwowych zaangażowanych w przekazywanie informacji nocyceptywnej. Siła uzyskanego efektu przeciwbólowego uzależniona jest od trzech czynników: ilości enkefalin uwolnionych w odpowiedzi na bodźce bólowe, zagęszczenia receptorów opioidowych oraz stopnia inaktywacji enzymów degradujących [34]. Eksperymenty prowadzone na gryzoniach pokazały, że wzrost stężenia enkefalin spowodowany inhibicją neprylizyny jest zbyt niski aby wywołać działanie przeciwbólowe [34]. Fakt ten doprowadził do rozpoczęcia badań nad preparatami hamującymi aktywność aminopeptydazy N - drugiego, ważnego enzymu biorącego udział w degradacji endogennych opioidów [34].

W 2017 r. Fabisiak i wsp. przeprowadzili eksperyment sprawdzający przeciwbólowe właściwości enkefalin oraz inhibitorów enkefalinaz: sialofiny i opiorfiny w mysim modelu bólu trzewnego wywołanym rozciągnięciem ścian jelita grubego [31]. Sialorfina jest pentapeptydem wydzielanym przez śliniankę podżuchwową szczura oraz prostatę dorosłych męskich osobników w odpowiedzi na stres środowiskowy [35]. Jako inhibitor neprylizyny oraz aminopeptydazy $\mathrm{N}$ zapobiega degradacji endogennych enkefalin uwalnianych w odpowiedzi na bodźce bólowe, zmniejszając tym samym przewodzenie informacji nocyceptywnej [36]. Ten sam mechanizm działania charakteryzuje drugi z badanych inhibitorów - opiorfinę, która jest ludzkim homologiem sialorfiny [35]. Wyniki badań ukazały, że podskórne podanie zarówno Leu-enkefaliny, jak i sialorfiny $\mathrm{w}$ dawce $1 \mathrm{mg} / \mathrm{kg}$, znacząco zmniejszyło siłę skurczu mięśni brzusznych w odpowiedzi na insuflację balonika w świetle jelita. Aktywności przeciwbólowej nie wykazywała natomiast opiorfina, co może wskazywać na obecność w ustroju enzymów degradujących ten związek lub specyficzność międzygatunkową [31].

\section{POTENCJALNE ZASTOSOWANIE INHIBITORÓW ENKEFALINAZ W TERAPII NIESWOISTYCH CHORÓB ZAPALNYCH JELIT}

Do grupy nieswoistych chorób zapalnych jelit (NChZJ) zalicza się wrzodziejące zapalenie jelita grubego (WZJG) oraz chorobę Leśniowskiego-Crohna (ChLC). Według aktualnej koncepcji etiopatologicznej do rozwoju NChZJ dochodzi na skutek nadmiernej odpowiedzi immunologicznej ustroju na mikrobiotę jelitową u osób predysponowanych genetycznie. Nieprawidłowości w funkcjonowaniu układu immunologicznego skutkują rozwojem przewlekłego stanu zapalnego obejmującego przewód pokarmowy [37]. Wczesne rozpoznanie choroby i zastosowanie skutecznej farmakoterapii pozwala na osiągnięcie długiego czasu remisji, zmniejszenie powikłań oraz odsunięcie w czasie konieczności leczenia chirurgicznego [38]. W terapii NChZJ stosuje się m.in. glukokortykosteroidy, aminosalicylany, leki immunosupresyjne oraz preparaty biologiczne - głównie inhibitory czynnika martwicy nowotworów a (ang. tumor nercosis factor $a$, TNF-a) [39]. Jedną z najnowszych strategii proponowanych $\mathrm{w}$ farmakoterapii NChZJ jest celowanie $\mathrm{w}$ endogenny układ opioidowy [40].

Ekspresja receptorów opioidowych na powierzchni komórek układu odpornościowego świadczy o zaangażowaniu endogennego układu opioidowego (ang. endogenous opioid system, EOS) w regulację odpowiedzi immunologicznej. Endogenni agoniści receptorów opioidowych pełnią rolę mediatorów wpływających m.in. na proliferację limfocytów typu T, aktywność cytostatyczną komórek NK, produkcję przeciwciał przez limfocyty typu B oraz wydzielanie cytokin [41]. Przypuszcza się, że najważniejszą rolę w regulacji funkcjonowania układu immunologicznego odgrywa receptor MOR [42]. U myszy z delecją genu kodującego receptor MOR znacznie zwiększa się ryzyko śmierci spowodowanej stanem zapalnym jelit. Znaczenie tego receptora zostało także potwierdzone przez Philippe i wsp., którzy w 2003 roku odkryli właściwości przeciwzapalne jego selektywnych agonistów, DAMGO i DALDA w modelu zapalenia wywołanym kwasem 2,4,6-trinitrobenzenosulfonowym (ang. trinitrobenzenesulfonic acid, TNBS) [43].

Badania ex vivo potwierdziły związek pomiędzy zaburzeniami w funkcjonowaniu EOS a występowaniem NChZJ [42,44]. Owczarek i wsp. z Uniwersytetu Jagiellonskiego przeprowadzili analizę porównującą stężenie Met-enkefaliny w surowicy krwi oraz tkance błony śluzowej jelita grubego u pacjentów z NChZJ i osób zdrowych [44]. Zaobserwowano, że stężenie Met-enkefaliny we krwi pacjentów z ChLC (84,5pg/ml) i WZJG (101,5 pg/ml) jest znacznie niższe w porównaniu do grupy kontrolnej (119,5 $\mathrm{pg} / \mathrm{ml}$ ). Odwrotne rezultaty otrzymano analizując stężenie Met-enkefaliny w błonie śluzowej jelita osób zdrowych i pacjentów ze zdiagnozowanymi NChZJ. Zarówno w grupie ChLC, jak i WZJG poziom Met-enkefaliny we fragmentach tkanki okrężnicy był znacznie wyższy w odniesieniu do grupy kontrolnej [44]. Ponadto u chorych cierpiących na NChZJ zaobserwowano wzrost ekspresji MOR na poziomie mRNA we fragmentach tkanki jelita objętych zapaleniem [42]. 
Zwiększona ekspresja receptora MOR oraz wzrost stężenia endogennych peptydów opioidowych w błonie śluzowej jelita objętego stanem zapalnym może wskazywać na zaangażowanie EOS w patogenezę lub przebieg NChZJ [44]. W związku z tym najnowsze koncepcje terapeutyczne postulują wykorzystanie elementów EOS w leczeniu NChZJ. Jedna $\mathrm{z}$ nich koncentruje się na syntezie inhibitorów enkefalinaz, które poprzez wydłużenie okresu półtrwania endogennych peptydów opioidowych mogą regulować stan zapalny $\mathrm{w}$ obrębie jelit [45].

W 2017 roku Salaga i wsp. przeprowadzili eksperyment mający na celu zbadanie przeciwzapalnych właściwości sialorfiny. Analizę przeprowadzono na dwóch modelach zapalenia: wywołanego doodbytniczym podaniem TNBS oraz doustnym podaniem DSS (ang. dextran sodium sulphate). U zwierząt z zapaleniem wywołanym TNBS, sialorfina znacząco zmniejszyła aktywność mieloperoksydazy oraz grubość ścian jelit. Ponadto analiza makroskopowa pokazała poprawę stanu tkanki objętej zapaleniem po podaniu sialorfiny. W chronicznym modelu zapalenia oprócz wyżej wymienionych rezultatów zaobserwowano także zmniejszenie stężenia prozapalnych cytokin (TNF- $\alpha$ i IL-1 $1 \beta)$. Podanie antagonistów receptorów opioidowych wykazało, że efekt przeciwzapalny jest wywołany aktywacją receptorów MOR i KOR, co może wskazywać, że sialorfina działa hamująco również na enzymy degradujące dynorfiny [46]. Wyniki powyższego badania otwierają nowe perspektywy w poszukiwaniu leków przeciwzapalnych, mogących znaleźć zastosowanie w terapii NChZJ.

\section{PODSUMOWANIE}

Jedną z najnowszych koncepcji proponowanych $\mathrm{w}$ farmakoterapii zarówno ZDJ, jak i NChZJ jest celowanie w endogenny układ opioidowy. Enkefaliny uczestniczą w mechanizmach antynocycepcji, regulacji pasażu żołądkowo-jelitowego oraz odpowiedzi przeciwzapalnej. Ich wykorzystanie farmakologiczne jest jednak ograniczone ze względu na krótki okres półtrwania w ludzkiej surowicy. Alternatywą dla pacjentów zmagających się z przewlekłymi chorobami jelit mogą okazać się inhibitory enkefalinaz, które pośrednio aktywują receptory opioidowe. Wyniki eksperymentów przeprowadzonych na zwierzętach potwierdzają skuteczność tych związków w łagodzeniu bólu oraz stanu zapalnego $\mathrm{w}$ przewodzie pokarmowym. Ponadto hamowanie aktywności enkefalinaz nie wywołuje niepożądanych skutków towarzyszących regularnemu stosowaniu opioidów. Dane te stanowią solidną podstawę do dalszych badań nad wykorzystaniem inhibitorów enkefalinaz w terapii ZJD oraz NChZJ .

\section{PIŚMIENNICTWO}

1. Brook K, Bennett J, Desai SP (2017) The Chemical History of Morphine: An 8000-year Journey, from Resin to de-novo Synthesis. J Anesth Hist 3(2): $50-5$

2. Williams JT, Ingram SL, Henderson G, Chavkin C, von Zastrow M, Schulz S, et al. (2013) Regulation of $\mu$-opioid receptors: Desensitization, phosphorylation, internalization, and tolerance. Pharmacol Rev 65(1): $223-54$
3. Camilleri M, Lembo A, Katzka DA (2017) Opioids in Gastroenterology: Treating Adverse Effects and Creating Therapeutic Benefits. Clin Gastroenterol Hepatol 15(9): 1338-49

4. Szymaszkiewicz A, Storr M, Fichna J, Zielinska M (2019) Enkephalinase inhibitors, potential therapeutics for the future treatment of diarrhea predominant functional gastrointestinal disorders. Neurogastroenterol Motil 31(4): e13526

5. Schiöth HB, Fredriksson R (2005) The GRAFS classification system of G-protein coupled receptors in comparative perspective. Gen Comp Endocrinol 142(1-2 SPEC. ISS.): 94-101

6. Al-Hasani R, Bruchas MR (2011) Molecular mechanisms of opioid receptor-dependent signaling and behavior. Anesthesiology 115(6): 1363-81

7. Pathan H, Williams J (2012) Basic opioid pharmacology: an update. Br J Pain 6: 11-5

8. Przewłocka B (2017) Basic mechanisms of analgesic effects of opioids. Med Paliatywna w Prakt 11(2): 48-54

9. Mosińska P, Zielińska M, Fichna J (2016) Expression and physiology of opioid receptors in the gastrointestinal tract. Curr Opin Endocrinol Diabetes Obes 23(1): 3-10

10. Pert CB, Snyder SH (1973) Properties of opiate receptor binding in rat brain. Proc Natl Acad Sci U S A 70(8): 2243-7

11. Simon EJ, Hiller JM, Edelman I (1973) Stereospecific binding of the potent narcotic analgesic $[3 \mathrm{H}]$ etorphine to rat brain homogenate (opiate receptor/morphine/antagonist). Proc Natl Acad Sci U S A 70(7): 19479

12. Terenius L (1973) Stereospecific Interaction Between Narcotic Analgesics and a Synaptic Plasma Membrane Fraction of Rat Cerebral Cortex. Acta Pharmacol Toxicol (Copenh) 32(3-4): 317-20

13. Pradhan AA, Smith ML, Kieffer BL, Evans CJ (2012) Ligand-directed signalling within the opioid receptor family. Br J Pharmacol 167(5): 960-9

14. Kamysz E, Sobocińska M (2017) Potencjalne zastosowanie enkefalin w diagnostyce i terapii różnych chorób. Wiadomości Chem: 33-44

15. Sobczak M, Sałaga M, Storr MA, Fichna J (2014) Physiology, signaling, and pharmacology of opioid receptors and their ligands in the gastrointestinal tract: Current concepts and future perspectives. J Gastroenterol 49(1): 24-45

16. Galligan JJ, Sternini C (2017) Insights into the role of opioid receptors in the GI tract: Experimental evidence and therapeutic relevance. Handb Exp Pharmacol 239: 363-78

17. Holzer P (2009) Opioid receptors in the gastrointestinal tract. Regul Pept 155(1-3): 11-7

18. Farmer AD, Drewes AM, Chiarioni G, De Giorgio R, O'Brien T, Morlion B, et al. (2019) Pathophysiology and management of opioid-induced constipation: European expert consensus statement. United Eur Gastroenterol J 7(1): 7-20

19. Heel RC, Brogden RN, Speight TM, Avery GS (1978) Loperamide: A Review of its Pharmacological Properties and Therapeutic Efficacy in Diarrhoea. Drugs 15(1): 33-52

20. Wu PE, Juurlink DN (2017) Clinical Review: Loperamide Toxicity. Ann Emerg Med 70(2): 245-52

21. Moss S, Subramanian V, Acharya KR (2018) High resolution crystal structure of substrate-free human neprilysin. J Struct Biol 204(1): 19-25

22. Hamza H, Khalifa H Ben, Baumer P, Berard H, Lecomte JM (1999) Racecadotril versus placebo in the treatment of acute diarrhoea in adults. Aliment Pharmacol Ther Suppl 13(6): 15-9

23. Eberlin M, Mück T, Michel MC (2012) A comprehensive review of the pharmacodynamics, pharmacokinetics, and clinical effects of the neutral endopeptidase inhibitor racecadotril. Front Pharmacol 3: 1-16

24. Lecomte JM (2000) An overview of clinical studies with racecadotril in adults. Int J Antimicrob Agents 14(1): 81-7

25. Cézard JP, Duhamel JF, Meyer M, Pharaon I, Bellaiche M, Maurage C, et al. (2001) Efficacy and tolerability of racecadotril in acute diarrhea in children. Gastroenterology 120(4): 799-805 
26. Salazar-Lindo E, Santisteban-Ponce J, Chea-Woo E, Gutierrez M (2000) Racecadotril in the treatment of acute watery diarrhea in children. $\mathrm{N}$ Engl J Med 343: 463-7

27. Lacy BE (2016) Emerging treatments in neurogastroenterology: Eluxadoline - a new therapeutic option for diarrhea-predominant IBS. Neurogastroenterol Motil 28(1): 26-35

28. Adrych K (2018) Zespół jelita drażliwego w świetle najnowszych wytycznych. Forum Med Rodz 12(6): 224-33

29. Izzo AA (2013) Novel insights which may translate into treatments for irritable bowel syndrome. Front Pharmacol

30. Camilleri M, Boeckxstaens G (2017) Dietary and pharmacological treatment of abdominal pain in IBS. Gut 66(5): 966-74

31. Fabisiak A, Sobocińska M, Kamysz E, Fichna J, Zielińska M (2018) Antinociceptive potency of enkephalins and enkephalinase inhibitors in the mouse model of colorectal distension-proof-of-concept. Chem Biol Drug Des 92(1): 1387-92

32. Danzebrink RM, Green SA, Gebhart GF (1995) Spinal mu and delta, but not kappa, opioid-receptor agonists attenuate responses to noxious colorectal distension in the rat. Pain 63(1): 39-47

33. Larsson MH, Bayati A, Lindström E, Larsson H (2008) Involvement of $\mathrm{K}$-opioid receptors in visceral nociception in mice. Neurogastroenterol Motil 20(10): 1157-64

34. Roques BP, Fournié-Zaluski MC, Wurm M (2012) Inhibiting the breakdown of endogenous opioids and cannabinoids to alleviate pain. Nat Rev Drug Discov 11(4): 292-310

35. Sobocińska M, Maćkiewicz Z (2014) Charakterystyka endogennych inhibitorów enzymów rozkładających enkefaliny. Wiadmości Chemiczne 68: 317-327

36. Rougeot C, Messaoudi M, Hermitte V, Gaëlle Rigault A, Blisnick T, Dugave C, et al. (2003) Sialorphin, a natural inhibitor of rat membrane-bound neutral endopeptidase that displays analgesic activity. Proc Natl Acad Sci U S A 100(14): 8549-54
37. Blumberg RS (2009) Inflammation in the intestinal tract: Pathogenesis and treatment. Dig Dis 27(4): 455-64

38. Wojtuń S, Gil J, Szwed Ł, Dyrla P (2014) Podstawowe objawy i różnicowanie nieswoistych chorób zapalnych jelit Basic symptoms and differentiation of inflammatory bowel diseases. Pediatr Med Rodz 10(1): 61-6

39. Gonciarz M, Szkudłapski D, Mularczyk A, Radwan P, Kłopocka M, Bartnik W, et al. (2017) Wytyczne postępowania z chorymi na nieswoiste choroby zapalne jelit w praktyce lekarza rodzinnego. Lek POZ 1: $1-11$

40. Koch G (2017) Medicinal Chemistry. Chimia (Aarau) 71(10): 643

41. Eisenstein TK (2019) The Role of Opioid Receptors in Immune System Function. Front Immunol 10: 1-20

42. Philippe D, Chakass D, Thuru X, Zerbib P, Tsicopoulos A, Geboes K, et al. (2006) Mu opioid receptor expression is increased in inflammatory bowel diseases: Implications for homeostatic intestinal inflammation. Gut 55(6): 815-23

43. Philippe D, Dubuquoy L, Groux H, Brun V, Van Chuoï-Mariot MT, Gaveriaux-Ruff C, et al. (2003) Anti-inflammatory properties of the $\mu$ opioid receptor support its use in the treatment of colon inflammation. J Clin Invest 111(9): 1329-38

44. Owczarek D, Cibor D, MacH T, Cieśla A, Pierzchała-Koziec K, Sałapa $\mathrm{K}$, et al. (2011) Met-enkephalins in patients with inflammatory bowel diseases. Adv Med Sci 56(2): 158-64

45. Kamysz, Sałaga, Sobocińska, Giełdoń (2017) Anti-inmflammatory effect of novel analogs of natural enkephalinase inhibitors in a mouse model of experimental colitis. Chimia (Aarau) 71(10): 643

46. Salaga M, Mokrowiecka A, Jacenik D, Cygankiewicz AI, Malecka-Panas E, Kordek R, et al. (2017) Systemic Administration of Sialorphin Attenuates Experimental Colitis in Mice via Interaction With $\mathrm{Mu}$ and Kappa Opioid Receptors. J Crohns Colitis 11(8): 988-98

\title{
Enkephalinases as a new pharmacological target in the treatment of gastrointestinal tract disorders
}

\author{
Agata Twardowska, Jakub Fichna, Agata Binienda ${ }^{\varpi}$
}

Department of Biochemistry, Faculty of Medicine, Medical University of Lodz, Lodz, Poland

${ }^{\otimes}$ Corresponding author: agata.binienda@gmail.com

Keywords: endogenous opioid system, enkephalinases, irritable bowel syndrome, inflammatory bowel disease

\section{SUMMARY}

Enkephalinases, which belong to the family of zinc metalloproteases play a crucial role in modulation of the endogenous opioid system (EOS) activity. Enkephalinase inhibitors (EI) allow obtaining therapeutic concentrations of selected endogenous peptides. One of the first EIs, racecadotril possesses antidiarrheal properties. Moreover, there is evidence that racecadotril presents fewer adverse events compared to other medications used for the treatment of diarrhea, such as loperamide. Lower potency for developing serious adverse events may be the key to choosing EIs as the preferred therapy in patients with chronic diseases. Additionally, EOS is involved in pain modulation, hence EIs might also be used as potential medications in treatment of pain. This review discusses the use of EIs in the treatment of gastrointestinal diseases, including irritable bowel syndrome and inflammatory bowel disease. 